Saint Louis University School of Law

Scholarship Commons

All Faculty Scholarship

1996

\title{
Disciplinary Actions and Pain Relief: Analysis of the Pain Relief Act
}

Sandra H. Johnson

Saint Louis University School of Law

Follow this and additional works at: https://scholarship.law.slu.edu/faculty

Part of the Health Law and Policy Commons

\section{Recommended Citation}

Johnson, Sandra H., Disciplinary Actions and Pain Relief: Analysis of the Pain Relief Act (1996). Journal of Law, Medicine and Ethics, Vol. 24, No. 4, p. 319, 1996.

This Article is brought to you for free and open access by Scholarship Commons. It has been accepted for inclusion in All Faculty Scholarship by an authorized administrator of Scholarship Commons. For more information, please contact erika.cohn@slu.edu, ingah.daviscrawford@slu.edu. 


\title{
Disciplinary Actions and Pain Relief: Analysis of the Pain Relief Act
}

\author{
Sandra $\mathrm{H}$. Johnson
}

he problem is pain, Paticnts and their families cell
thic story:

He is your son. You love him. You want to help him in every way you can, but when he is in that kind of pair, you are helpless in a sensc.... l'm his daddy. It was-what was I supposed to do for him? I felt, you know, helpless.

It terrifies you. You want to run away from it. Pain is something you wish would kill you but does not. Agouy resilts from the pain that does not have the decency to knock you out. ${ }^{2}$

$[W]$ e had a good family, but how much can you watrh? How much sulfering can you watch from your child, your 7-year-old child, and still keep your mind?

I am: a forty-six-ycar-old registered nurse who specializes in oncology care and education. I am also a patient who suffers from chronic nommalignant pain, and this malady has been the most frightening, the most humiliating, and the most difficult ordeal of my life....

The general tenor of the medical advice that was given to me was this: I would just have to learn to live with the pain....

... I found myself begging, as though I were a criminal. Defensive and angry and yet in such great need, I would beg forgivencss for having this pain. I became withdrawn, completely disabled by my terrible, relentless pain. I was unable to function profession-

Journal of Law, Medicine \& Ethics, 24 (1996): 319-27.

(c) 1996 by the American Society of Law, Medicine \& Fthics. ally. I was unable to be much of a wife or a mother, a daughter or a friend....

... Now, when I see unnecessary suffering caused by intractable, "mismanaged" chronic pain, I am disgusted. As a health care provider, I am ashamed. ${ }^{4}$

Dcbilitating pain is a widespread problem that cuts across many paticnt populations. For example, 75 percent of cancer patients in one study reported suffering pain, with 40 to 50 percent reporting moderatc to severe pain and 2.5 to 30 percent reporting severe pain. This occurs even though 90 percent of cancer pain can be relieved through "relatively simple means." " Chronic nonmalignant pain has been described as "an extremely prevalent problem." Over two-thirds of nursing home residents experience serious chronic pain. ${ }^{7}$ Morcover, the elderly, minorities, women, children, and those unable to spcak for themselves due to disability bear the brunt of ineffective care and are undertreated at cven higher rates than others. ${ }^{x}$ But despite the devclopment of effective pain management interventions and the overall human and financial cost, pain is neglected and undertreated.

The ethical duty to relieve pain is well established. The Agency for Health Care Policy and Research (AHCPR) founds its pain management guidelines on this principle: "The cthical obligation to manage pain and relieve the patient's suffering is at the core of a health care professional's commitment."

Health care professionals offer many reasons for the undertreatment of pain, and an effective response to the problem requires an effort on several fronts. Health care professionals require much more effective education and training in the treatment of pain. Institutions must remove unnecessary institutional barriers to pain relief and should ensure that effective pain management is an institutional 
priority. l'ayment systems should realize the costs of pain and adequately support pain control. Patients and caregivers must also be informed and assured that pain relief is to be expected and that fears of addiction are unfounded. ${ }^{10}$

One source of the problem, according to physicians, is the threat of legal sanctions for treating paticnts in pain, cspecially when that treatment must rely on the use of corjtrolled substances. Doctors have reported that they undertreat for pain, in part, from fear of legal penaltics, cspecially disciplinary action. " In a California survey, 69 percent of respondents said that the potential for disciplinary action made doctors more conservative in their use of opioids in pain management, and a third reported that their own patients may be suffering from untreated pain. ${ }^{12}$ Another review of published research on the undertreatment of pain concluded that "available data suggest that medical decision-making regarding the use of opioids continues to be unduly influenced by regulatory policies and fear of regulators." 1.3

Doctors' fears of disciplinary action and criminal prosecution are justified. There is no evidence that large numbers of physicians are sanctioned for their treatment of patients in pain, but the impact of the process on those physicians who are only investigated, or only charged but not disciplined, or only warned or cautioned but not penalized is severe. The prosecutorial stance stimulated by a "war on drugs" and by increasing public scrutiny of disciplinary agencics may unintentionally interferc with adequate pain relief because it has intensified and criminalized investigations and later proceedings. Descriptioins of the investigation of physicians engaged in the treatment of pain patients with controlled substances present a scenario that would easily intimidate most people. ${ }^{14}$ Some evidence also suggests that many state medical boards have not adapted to more current approaches to the use of controlled substances in pain management and that they may rely solely or too heavily on dosage and length of treatiment as indicators of inappropriate and illegitimate prescription practices. ${ }^{15}$ Greatly increased cnforcement efforts in Medicaid programs may also have an impact on prescribing practices in the treatment of pain, though these are still being evaluated. ${ }^{16}$

Review of the case law involving disciplinary actions against physicians for their prescriptive practices also reveal that the disciplinary process is not entircly successful in distinguishing between "good doctors" who are providing effective medication to patients experiencing pain and "bar! doctors" who are providing controlled substances to patients when it is not appropriate. Brief discussion of two cases illustrates the point.

In a 1995 opinion, the Lousiana Court of Appeals in In the Matter of DiLeo ${ }^{17}$ reviewed the case of a physician whose license had been suspended by the State Board of Medical Examiners for his treatment of seven chronic pain patients with cointrolled stibstances. 'The prosecution's cxpert witness tesified that the physician maintained more detailed modical records on his pationts than most physicians in general practice did; that the patients did suffer legitimate chronic pain; and that the dosages used were not excessive. The sole basis for the expert's testimony against the physician was the length of time during which the medication was prescribed. Citing only the Physician's Desk Reference, the expert indicatcd that the drugs were only intended for short-tem use. The expert, an addictionologist, testificd that the drugs were addictive over the long term. The appellate court rejected the board's suspension of the doctor's license. The court concluded that he liad acted in good faith and reasonably believed that the patients were suffering pain; that his patients had suffered serious iniury or medical complications that warranted the ase of pain medication; and that there was no evidence of diversion or improper use. The physician had first been charged with a violation of the state medical practice act in May 1992, and the board's appeal of this 1995 courit of appeals decision was denied in Febriary 1996, nearly four years later. ${ }^{18}$

In 1996, the lonida Couri of Appeals reviewed a disciplinary action in Hoover $v$. Agency for Health Cam Administration, ${ }^{1 "}$ where the state board liad imposed a $\$ 4,000$ fine, had required the doctor to complete continituing med. cal cducation oi the prescription of "abusable" drugs, and had placed the physician on wo ycars' probation. In this case, the board had assessed these penalties despitc the fact that the administrative hearing officer found that the board had failed to prove any of its charges. The board had presented two physicians who testificd as experts at the administrative haring in support of the board's charges; but neither had examined any of the patients or their medical records, and they testified solely on the basis of pharmacy records of the drug and the amouni prescribed. The appetlate court, in its review, inoted that these testifying physicians themselves did not treat chronic paii patients. The court concluded that "[d]espite this paticity of evidence, lack of familiarity, and secming lack of expertise" the state's physicians testified that the defendant had prescribed "excessive, perhaps lethal amounts of narcotics, and liad practiced below the stanidard of care." The couri set aside the board's penalties. The court further noted that it was "siirprising to see agency disciplinary action based 11 pon sich ? paucity of evidence after [the court's] admonitions" in a case some years carlier, ${ }^{21}$ concerning inadequacy of evidence in cases involving treatmerit decisions. ${ }^{21}$

These cases evidence substantial problems in the process and the proof used to prosecute the defendant physicians. As would be expected, the mumber of such appellate cases is not large, in pari because very few cases are litigated to the appellate level. ${ }^{2}$ In addition, the nainter of judicial opinions may be small because disciplinary ageir- 
cics and prosccutors may undertake investigations and impose no official sanction while limiting the professional's practice or requiring remedial action as a consensual resolution to the threat of disciplinary action..$^{23}$ Further, it appears likely that the number of physicians actually penalized for their prescriptive practices in treating patients for pain is not large, although the statc agencies interviewed for the Project on Legal Constraints on Access to Effective Pain Relief (the Project) were not ablc to separate actions against physicians treating patients for pain from the more general disciplinary category of abuse of prescription drugs. ${ }^{24}$ As described carlier, however, the threat of disciplinary action or prosection is itself severe because of the burdens imposed by the investigation and proceedings themselves.

Investigations and hearings are a necessary part of effective professional discipline and criminal prosecution for suspccted illegal drug activity or incompetent care. But even if the health carc provider is exonerated in the end, the investigations and proceedings almost unavoidably cause substantial injury to the provider, in terms of financial, professional, and emotional consequences. The licensce's ultimate success in defending his/her actions after lengthy proceedings does not ameliorate these effects. Effective early cvaluation or stopping points must be bujlt into the system if fear of legal sanction is to be rnitigated as a cause of ineffective care of patients in pain. The actual risk of an inappropriate legal sanction against physicians treating vaticuss in pain is likely somewhat less than physicians imagine; but the severity of the consequences of disciplinary or criminal processes may lead doctors to weigh the risks very heavily.

The Pain Relief Act ${ }^{25}$ responds to the problem of neglected pain by addressing the risk of inappropriate legal sanctions against health care professionals. In protecting them, however, the Act accounts for legitimate goals underlying discipline and prosecution.

Disciplinary and prosecuting agcncies are concerned with impaired providers who self-prescribe controlled substances or divert drugs to their own use. ${ }^{2.6}$ They are concerned with professionals who arc incompetent or fraudulent in their pescriptive practices, because such practitioncrs present a physical or financial threat to their patients by prescribing controlled substances where the medication is believed to be ineffective or dangerous. ${ }^{27}$ Prosecutors arc concerned with abuses of govermment health care programs, induding Medicaid. ${ }^{28}$ State disciplinary boards arc also involved, often in collaboration with criminal prosecutors, in the war against drugs, penalizing providers who prescribe controlled substances that can be diverted to street use or who themselves deal drugs using their prescriptive authority. ${ }^{24}$ Unfortunately, disciplinary and prosecutorial efforts to achicve these regulatory goals ninay be discourag$i_{1}$, health carc professionals from providing ethically and medically necessary care.
A number of approaches may contribute to resolving the tension in policies underlying disciplinary actions and prosecutions relating to treatment for pain. Important work has been done by some boards of medicine, for example, in devcloping internal policy statements concerning their disciplinary stance toward the issue. ${ }^{30}$ A statitory approach makes a unique contribution.

\section{Why a statute?}

Written administrative policies can neutralize the fear of legal sanction if these policies are broadly disseminated among the health carc professions and are observed at all levels of the state professional disciplinary agency. A legislative response to the impact of legal sanctions on cffective treatment for pain is, however, desirable under many circumstances. A state statute can serve sevcral purposes.

State agencies are charged with achieving a number of pubtic policies in their legal actions against health care professionals for the prescription of controlled substances. Among these cleaily stated policics are decreasing the illicit supply of drugs and reducing the costs of certain government-supported health care programs. A statute clearly removing the threat of adverse government action for competent pain management will establish authoritatively a state policy of ensuring access to effective relicf of pain. This would allow a pro-pain-relief policy to take its place among other statutorily expressed and casily understood policies. A legislative statement of public policy may also be used by the courts in cases related to pain management in other legal contexts. A statute can be a powerful step in placung pain control at the same level as drug control in state policy making.

A state statute may exert a greater influence over prosecutors and over the lawyers representing the boards in investigations, hearings, and appeals than a policy statement. State government agencies, including disciplinary boards and prosecutors' offices, often experience significant staff and membership turnover, including their legal represcntation. $\Lambda$ clearly articulated statute provides legal continuity across these staff, membership, and representation changes. In an intervicw survey of a number of state medical boards, the Project found senior staff with responsibility for professional discipline who were not aware of appellate court opinions in their own states even when the opinion had set an evidentiary standard for disciplinary actions relating to treatment for pain and that had directed the boards to alter their practices. ${ }^{31}$

Adoption of a pain-relief policy by a single professional state disciplinary agency governs that agency's own actions, and such a policy may satisfy professionals governcd by that board. But effective pain management, including the prescribing, dispensing, and administering of controlled substances, involves other professionals. The successful 
policy making accomplished by one board may have to occur across several state agencies and with the prosecutors who have discretion to act under state criminal law, to ensure that their policy effectively protects all providers who are significantly involved in pain management.

A pain relief statutc also provides an extcrnal standard by which board policies and actions can be reviewed. In a state that is up to date on its controlled-substances policy in medical treatmont, the Act would not impede effective discipline. In a state that persists in very restrictive policies or in formal or informal activity that works against effective treatment, a statute gives a court a legal basis on which to review the board's policies, standards, investigative activity, and both formal and informal actions. Where health care professionals are faced with repeated investigations or letters of concern that appear to threaten but never actually proceed to formal action, a statute may provide them, or the organizations that employ them, with a basis for a declaratory judgment action. ${ }^{32}$

Several states have already enacted "intractable pain" statutes, and others are considering them. These statures vary widely among the states. The Pain Relicf Act is compared with these existing state statutes in the last section of this commentary.

\section{The Pain Relief Act}

The following discussion reviews the major provisions of the Pain Relief Act. The first section outlincs the opcration of the Act. The second section offers a detailed discussion of the Acr's major provisions.

\section{Structure}

The primary goal of this Act is to terminate actions against providers engaging in justifiable pain management practices as early as possible in the disciplinary or criminal process. The objective is to prevent unnecessary investigations, protracted proceedings, and inappropriatc legal sanction. To this end, the Act provides that disciplinary action or state criminal prosecution cannot be brought against a health care provider under certain circumstances. Where such action is brought, the Act scts a procedural and substantive standard for the evaluation of the professional's practices.

The structure used to create this shield for providers engaged in appropriate treatmenc practices is a form of rebuttable presumption. A provider meeting the standards specified in the Act is presumed to be in compliancc with disciplinary standards and criminal law; however, the disciplinary board or prosecutor may rebut the provider's demonstration of compliance with the Act's standards with clinical expcrt testimony.

Any legislation or rule that distinguishes acceptable from unacceptable practices must make reference to some standard of practice. For example, living will statutes that provide immunity to physicians who comply with a patient's advance directive frequently require simply that the physician act in "good faith." 'The Pain Relief Act does not adopt a good-faith standard for its protection of health care professionals because that standard would allow professionals who provided incompetent pain management to escape disciplinary action or prosecution.

Statutes or rules regulating professionals often require that the professional conform to "accepted standards of practice" or "customary practice." Similarly, a statute designed to shield health care professionals from inappropriate legal sanction could expressly provide that only those professionals who conform to the standard of care or to customary practice are shielded. Such standards are couniterproductive in regulating pain management because current professional practices are generally viewed as inadequate, with undertrcatment and mistreatment being significant problems.

The use of very broad terms such as "standards of practice," "accepted medical practice," or "customary practice" presents a second problem because they require extensive proof and testimony io fill in the specific content. Reference to standards of practice or cistomary practice may be ambiguous because the legal connotation of standards of practice can include both "customary," "best," and "accepted" practices. Reliaince on a standard that requites cxtensive proof or that is ambiguous would defeat the Act's purpose of avoriding protracted proceedings and terminating disciplinary and criminal procedings as early as possible where appropriate. I.ess ambiguous standards should provide professionals with more confidence that their treat. ment of patients for pain will not trigger investigation for disciplinary action or criminal prosecution.

Providing a shicld for providers who act in good faith may too easily protect incompetent providers. P'roviding at shicld for providers who engage in accepted medical practice can codify inadequate practices and require physiciais to stay well within the mainstream instead of adopting current more aggressive approaches to pain managencist.

The Pain Relief Ast incorporates accepted practicc/care guidclines as the standard for a shicld from disciplinary or criminal actions. The Act does not require compliance with accepted practice guidelines, however. In fact, it specifically states that depaiture from accepted guidelines is not sufficient evidence on its own to support adverse action against the provider. Instead, compliance with accepted practice guidelines provides only a deferisi to disciplinary action or criminal prosecution.

fo reccive the protection of the Ast the professional must be in substantial compliance with accepted practice guidelines. Substantial compliance, as a $\mathrm{kgal}$ term, means conformity with essential requirements. It requires consid- 
erably more than minimal but less than absolute compliance. Reguiring stsict or absolute conformity with guidelines places a severe burden on a provider and is inconsistent with the structure and form of practice guidelines generally.

Those providers who educare themselves about current guidelines available in their field for the treatment of pain patients - and observe those guidelines in their own practices---receive the bencfit of protection from discipline and criminal prosecution. On the other hand, accepted guidelines only play a protective role, and evidence of noncompliance is insufficient to support action against the provider. In other words, accepted guidelines can be used as a shield, not a sword, against the health care professional.

To be protected under the Act, the provider must also comply with the standards of practice specifically identified in the Act., including maintendnce of accurate and complete medical rccords, physical examination of the patient, documentation of a trcatment plan, among other criteria. The Act also prohibits false or fictitious prescriptions and diversion of medication prescribed for a patient to the provider's own use. These standards have been viewed in the case law as important indicators of good-faith treatment for pain. ${ }^{33}$ Applying these statutory standards would screen effectively for the most serious violators of ordinary standards of practice.

The fict requires that a board or prosecutor produce testimony of a clinical expert to rebut a provider's demonstration of compliance with an accepted guidelinc for care of patients with pain. The requirement that the board or prosecutor involve a qualificd expert (as defined in the Act) early in the process operates as an important check on inappropriaie cnforcement actions. The Act also requires a board or prosecutor to provide testimony of a clinical expert to support its finding or charge of violation should proceedings be pursued.

\section{Specific provisions}

Language in brackets in the text of the Act indicates the point at which individual states should provide language that reflects thicir own statutory framework. For example, in Section 2, the Act does not identify the individual boards by title but rather brackets that item for insertion of the appropriate identifier in each state.

\section{"Health care providers"}

The Pain Relief Act reaches all licensed health care providers whose prescription, dispensing, or administration practices in pain relicf may trigger disciplinary action or prosccution. It is not limited to physicians, as are current statutes and policies.

This broad scope is particularly important becausc many statcs are now recognizing prescriptive authority for advanced practice nurses and physician assistants. Further, the delivery of much of health care has shifted to settings such as long-terni carc, nursing homes, homc care, and hospicc, where most of the direct pain care is performed by nurses rather than physicians, even in the absence of prescriptive authority for controlled substances. In collaborative practice settings, nurses and physician assistants remain accountable to thcir own professional discipline boards, independent of the boards of medicine that regulate physicians.

\section{"Intractable pain"}

The Act uses intractable pain because that term is commonly used in similar state statutes. The Act does specify that intractable pain can be temporary, and this is consistent with the ordinary meaning of intractable, although the connotation of the term is sometimes taken to be long term only. The statutory definition is nor limited to particular physical conditions and so would apply to chronic nonmalignant pain and other pain states.

\section{"Clinical expert"}

It is important that the provider who more aggressively treats patients in pain consistent with ncwer standards of care be cvaluated only by professionals who themselves are knowledgcable about effective pain relicf. Current law in many states does not requirc that a disciplinary board engage an expert in proving a claim of violation of disciplinary standards. ${ }^{34}$ Wherc an expert is required, the courts generally afford the board wide latitude in the qualifications of the cxpert. In criminal prosecutions, qualifying the experts who will evaluate the provider's practices for the jury is key. Both of the appellate court cases described earlier can be viewed as actions in which the board's cxperts were inadequate to prove that the defendant physician had violated the law.

Under the Pain Relief Act, the board or criminal prosecutor is required to provide a qualified clinical expert to support the case against the provider. By the specific terms of this Act, the expert is one who "by reason of spccialized education or substantial relevant experience in pain management has knowledge concerning currett standards, practices, and guidelines." The licensce is not required to provide expert testimony.

\section{"Accepted guideline"}

The Act protects a health care professional from the threat of legal sanction if the professional substantially complies with accepted guidelines for the treatmeat of pain. As discussed previousiy, substantial compliance with such guide- 
lines provides a shield against legal penalty. The Act specifically states, however, that a health care provider is not to be penalized for noncompliance with accepted guidelines.

The Act limits the statutory recognition of accepted guidelines to thosc produced by nationally recognized clinical or professional associations, specialty societies, and government agencies. A number of organizations would satisfy the statutory description, including AHCPR, the American Pain Society, the Amcrican Society of Clinica! Oncology, and so on..$^{35}$ The Medical Board of California, for example, has specifically referred to AHCPR guidslines, "which have been cndorsed by the Board as a sound yet flexiblc approach to the management of [trauma, surgery and cancer] pain." ${ }^{.36}$

The Act excludes guidelines devcloped primarily for coverage, payment, or reimbursement because those guidelines may be issued for cost-containment purposes. Although cost containment is a legitimatc goal, it does not serve the purposes of this Act.

The Act allows the provider to select from muitiple sources for guidance in fashioning or defending his/her own practices, allowing for diverse practices of professionals and medical specialties. Allowing guidelines from multiple sources to function within the Act also addresses potential resistance from health carc providers, and especially physicians, toward practice or care guidelines. Providers continue to have the freedom to sclect the patterns of practice that best serve their patients.

The use of accepted guidelines should also address another deficiency in pain management practices by raising the awareness of current standards of pain management within the professions. Physicians and nurses give many reasons for undertreating pain, including lack of knowledge. The Act's recognition of substantial compliance with accepted guidelines as a defense to disciplinary action or criminal prosecution provides a substantial incentive for hcalth care professionals to increase their knowledge of pain management techniqucs and strategies.

Guidelines are not currently available for all areas of pain management. Where guidelines are undevcloped, the statute specifically gives a board authority to develop its own policies and rules, but these must be consistent with the goals of the Act. The Act itself may in fact prompt boards to fill in the gaps through rule making or policy making rather than through adjudication of individual cases. Case-by-casc enforcement, absent statutory or administrative standards, has the unfortunate consequence of testing, basic principles and standards at the expense of individual providers. This increases fear of sanction and fear of scritiny.

It is important, though, that the Act does not place the burden on boards to develop practice or care guidelincs. In 1991, the Government Accounting Office reported that medical specialty societies spent one to three years and up to $\$ 130,000$ on a single guideline development project, a cost that did not include the value of time donated to the professional society. ${ }^{37}$ Boards are not able to bear such a burden under current restrictive state budgets.

\section{"Disciplinary action"}

Disciplinary interventions frequently result in informal resolution. If the Act is to protect and encouragc providers whose practices comply with an accepted guideline and specific statutory practice standards, informal resolutions should meet the same standards of good practice. The Act, therefore, reaches both formal and informal actions and both remedial and punitive actions.

\section{Chemically dependent patients}

Pain does not discriminate. Paticnts who are drug-dependent may experience severe pain unrelated to their dependency. They are equally or perhaps more likely to contract painful diseases such as AIDS or to experience injuries or disabilities that may cause chronic pain. Using the patient's preexisting condition as a serious obstacle to adequate treatment of intractable pain is punitive of their status and causcs avoidable suffering.

Current legal restrictions on the treatment of chemically dependent patients in pain penalize patients suffering from intractable pain, as well as the licensed professionals directing their carc. These legal restrictions are not always well designed and may usc inaccurate, inadequatc, or ambiguous definitions of dependency or addiction. ${ }^{38}$ Restrictions on access to pain medications may also have a severe and adverse effect on the treatment of AIDS paticnts and an adverse impact by race.

The Act, therefore, expressly extends its protection to providers in their treatment of chinically dependent or addicted paticnts for pain. The Act, however, specifics a broader authority on the part of the boards to establish both standards and procedures for the application of the Act to this patient population. This siructure will accommodate variation in state law and policy in this particular arca, although standards and procedures developed by the boards must be consistent with the Act's purpose of encouraging the provision of effective pain relief.

\section{Comparison to current statutes}

Several states have cnacted pain statutes, ${ }^{39}$ or are considering legislation. ${ }^{13}$ The Pain Relief Act differs from some stat. utes in significant ways, and attempts to address shortcomings in existing statutes.

The Pain Relief Act is broader in its scope than all current state statutes in two aspects. First, the Ace reaches 
all professions with significant involvement in the treatment of pain; it is not confined to physicians. Second, the Act reaches both disciplinary action and criminal prosecution. Of course, states may choose to modify the Act by reducing its scope to certain professions or to disciplinary actions cnly.

Conversely, the Act is narrower than some state statutes in its scope of protection because it does not provide absolute immunity for professionals treating patients in pain; instead it provides significant protection to health care providers who can show substantial compliance with certain standards of practice. At the same time, however, the Act does not penalize providers who cannot demonstrate compliance with any practice guideline. Noncompliance cannot provide the basis of adverse action against any provider.

California's statute provides that "no [doctor] shall be subject to disciplinary action ... for prescribing or administering controlled substances in the course of treatment ... for intractable pain" as long as prescription of controlled sulsstances is for a "rherapcutic purpose" and meets requiremerits similar to those in Section 4 of the Act. ${ }^{41}$ Similar statutory immunity provisions relating only to disciplinary action and only for physicians have been adopted by Nevada, Oregon, and Texas. ${ }^{42}$ Although such statutes appear to afford physicians broader protection, the standards with which the physician must comply are comparatively nondeterminative. For such statutes to be effective, the boards must take appropriatc action through rule making or other such activity to rectify the ambiguities of the statutory standard. Where boards have taken such action, the more ambiguous statutory standard may operate effectively; but absent such action, such a statute may provide little encouragement for effective treatment of pain in the face of legal uncertainty.

Virginia's statute simply states that a physician may use controlled substances for the treatment of patients in pain. ${ }^{43}$ This statute does not specify what legal cffect this statement is to have. It does not directly address standards to be used in disciplinary action, except to state that the statute does not grant immunity. It does not establish a legal standard that effectively responds to fear of disciplinary action.

Several current state statutes rely on general standards of medical practice in the treatment of pain. For example, Florida's statute simply refers to the "level of care, skill, and treatment recognized by a reasonably prudent physician under similar circumstances." "44 Nevada's statute similarly refers to "accepted standards for the practice of medicine." The Pain Relicf Act, because it aims to terminate disciplinary procecdings or criminal action at an carly point in the process and because it aims to communicate a predictable and reliable standard to professionals concerned about the risk of legal sanction, uses a more spccific standard.
The Act is similar to the existing state statutes in spccifying other required standards of practice. These include the maintenance of written paticnt records; physician examination of the patient; the establishment of a treatment plan; and other clinical and practice management actions.

The Act does not requirc a second medical opinion about the causc of the patients' pain, although a few of the current statutes do. California's statute, for example, rcquires cvaluation by "the attending physician or surgeon and one or more physicians or surgeons specializing in the treatment of the area, systcm, or organ of the body perceived as the source of pain." "'t Requiring a second medical opinion, especially from a specialist, may create significant access and payment problems for pain patients.

The Pain Relief Act differs from current statutes in its treatment of patients who are chemically dependent. At least three state statutes (North Dakota, Texas, and California) specifically exclude persons who are being treated by the physician for chemical dependency. ${ }^{47}$ Some provide that the physician may not provide controlled substances to "a person the physician or surgeon knows to be using drugs or substances for nontherapeutic purposes." 48

The Pain Relief Act, in contrast, specifies that the provisions of the Act do apply to patients who are chemically dependent or addicted. The Act specifically includes the trcatment of patients who are chemically dependent in order to offset restrictions that may negatively influence physicians in their treatment of patients who might be inappropriately considered "chemically dependent" because of their long-term use of opioids for the treatment of pain. Spccific inclusion should encourage, rather than discourage, professionals in treating chemically dependent patients in pain.

The Oregon statute stands alone in requiring the patient's written consent to pain medication. ${ }^{49}$ It requires that before beginning treatment for intractable pain, "the physician shall provide to the person and the person shall sign a written notice disclosing the material risks associated with the prescribed or administered controlled substances to be used in the coursc of the physician's treatment of that person." The Pain Relief Act docs not cstablish a special statutory requirement of written consent because trcatment for pain is governed by the ethical and legal franework already in existence for informed consent to treatment. A specific statutory requircment for written consent trcats medication for pain differently than other medications and so continues the notion that it is necessarily riskier or more dangerous. Requiring writtcn consent would raise significant issues for incompetent patients and may raise questions of cultural diversity that are currently being studied in regard to consent and advance directives.si

Intractable pain statutes are not the only state statutcs that currently limit legal sanctions against physicians in their treatment of patients in pain. Most living will or ad- 
vance directive statutes include direction to the physician that measures necessary for the relief of pain be employed. Several of these statutes, or the statutory forms provided within the statute, direct that pain relief be provided even if it might hasten death. ${ }^{51}$ Good-faith compliance with such an advance directive, within the terms of the state statute, usually confers immunity from civil and criminal liability. Living will statutes tend to be of limited application, however; they are almost always restricted to incompetent patients and, in most states, by the medical condition of the paticnt. Still, they provide a statement of state policy supportive of the alleviation of pain.

\section{Conclusion}

Needless human suffering from untreated but treatable physical pain is caused by a number of factors influencing health care professionals, health care institutions, payment systems, and patients and families themsclves. Fear of legal sanction is one reason for neglect of treatment. The Pain Relief Act, and similar statutory and administrative responses, can minimize fear of legal penalty for effective treatment of patients in pain. The Act identifies pain control as a priority for state health policy, and allows pain control to join drug control as an expressed policy of the state.

Efforts to align a state's professional regulatory system and other cnforcement activity behind the goal of relieving trcatable pain must also examine the processes used to investigate professionals charged with legal violations in relation to treatment of patients in pain. New models must be developed to shift oversight of pain management from a quasi-criminal context to another context more conducive to patient protection. Earlier in the history of profcssional regulation, the regulatory posture toward substance-abusing or otherwise impaired physicians changed significantly with the introduction of diversion and impaired-physician programs. Such physicians are no longer handled in a criminalized process. Nor are physicians who are charged with negligence. The regulatory approaches toward impaired physicians or toward disputes over treatment may offer other models for the investigation and prosecution of health carc professionals who meet at lcast minimum standards in their treatment of patients in pain.

\section{References}

1. As quoted in B.R. Ferrell, "The Impact of Pain on Quality of Life: A Decade of Research," Nursing Clinics of North America, 30 (1995): at 620 .

2. Id.

3. Id.

4. C.A. Snyder, "An Open Letter to Physicians Who Have Patients with Chronic Nonmalignant Pain," Journal of I aw, Medicine of Ethics, 22 (1994): at 204-05.

5. Research reviewed in Agency for Health Care Policy and Research, Management of Cancer Pain: Clinical Practice
Guidelines (Rockvilie: Dept. Health and Human Services, P'ub. No. 94-0592. Mar. 1994): at 4.

6. K.K. Porteioy, "Therapeutic Use of Opioids: Prescribing and Control Issues," in I.R. Cooper, D.J. Czechowicz, and S.P. Molinari, cds., Impaci of Prescription Drieg Diversion Control Systems on Medical Practice and Patient Care (Washington, D.C.: U.S. Government Printing Office, National Institute on Drug Abuse, Research Mono. 131, 1993).

7. B.A. Ferrell, B.R. Ferrell, and D. Osterwil, "Pain in the Nursing Homc," Joumal of the Ancrican Geriatric Society, 37 $(1990): 409$.

8. B.S. Shapiro and B.R. Ferrcll, "Pain in Children and the Frail Elderty: Simviarities and Implications," Amcrican Pain Society Bulletin, Oct./Nov. (1992): 1; and K.H. Knox, N. Samaroo, and J.R. Hoffman, "Ethnicity as a Risk Factor for Inadequate Emergency Department Analgesia," JAMA, 269 (1993): 1537-39.

9. Agency for Health Care Policy and Research, Acute Pain Management: Operative or Medical Procedures and Trasuma (Rockville: Dept. of Health and Human Services, Puh. No. 940592, Feb. 1992): at 4 (emphasis added). See also, Oninions of the Council on Ethical and Judicial Affairs, American Medical Association, Opinion 2.20 (1994).

10. N.I. Cherny and R.K. Portenoy, "The Management of Cancer Pain," Cancer, 44 (1994): at 287; and R. Melzack, "Thu: Tragedy of Necdless Pain," Scientific American, 262, no. 2 (1990): $27-34$.

11. F.J. Skelly, "Painful Barriers," American Medical News, May 9, 1994, at 15; F.J. Skelly, "Price of Pain Control: Is This the Risk You Face When Appropriately Prescribing Narcotiss for Pain?" American Medical News, May 16, 1994, at 17; and F.J. Skelly, "Fear of Sanctions Limits Prescribing of Pain Drugs," American Medical News, Altg. 15, 1994, at 19.

12. Sec Skelly (Aug. 15, 1994), id.

13. R.K. Portenoy, "Opioid Therapy for Chronic Nonmalignant Pain: A Review of the Critical Issues," Joumal of Pain and Symptom Management, 11 (1996): at 204.

14. Many narratives by professionals and agencies descitibe inspections related to the prescription of controlled substances. For a court's description of an investigation of suspected illegal prescriptive practices, see Howard $v$. Miller, 870 F. Supp. 340 (N.D. Ga. 1994). Ste also "General Counsel Defends State Medical Licensure Board," Joumal of the Oklaboma State Medical Association, Oct. (1993): 86 (responding to criticism of the board's handling of prescriptive practices cases) D.E. Joranson, "Controlled Substances, Medical Practice and the Law." in H.I. Schwartz, ed., Psychiatric Practice Under Fire (Washington, D.C.: American Psychiatric Press, 1994): 173-94; and O. Benton, "Innocent Victim of the Drug War?,"American Pain Sncieiy Bulletin, Feb. (1993).

15. D.E. Joranson et al., "Opioids for Chronic Cancer and Non-Cancer Pain: A Survey of State Medical Board Mernbers," Federation Bulletin: The Journal of Medical Licensure and Discipline, 79 , no. 2 (1992): 15-49.

16. General Accounting Office, Prescription Drugs and Med. icaid-Automated Review Systems Can Help Promote Safety, Save Money (Washington, D.C.: Gencral Accounting Office, May 30, 1996); and S.B. Sounerai ct al.. "A Critical Analysis of Studies of State Drug Reimbursement Policies: Rescarch in Need of Discipline," Milhank Quarterly, 71 (1993): 217-52

17. In the Matter of DiLeo, 661 So. 2d 162 (La. App. 1995).

18. See $i d$.

19. Hoover v. Agency for Health Cane Administration, 676 So. 2d 1380 (Flâ. Dist. Ct. App. 1996).

20. Snei⿱⺈ v. Depariment of Professional Regulation, Board of Medical Examiners, 454 So. 2 d 795 (Flia. App. 1984). 
21. See id.

22. Sce also Hollabaugh v. Arkansas State Medical Board, 861 S.W.'2d 317 (Ark. App. 1993); and Williams v. Tennessee Board of Medical Examiners, WL 420910 (Tenn. App. 1994).

23. See Group Health Plan, Inc. v. State Board of Registration for the Healing Arts, 787 S.W.2d 745 (Mo. App. 1990).

24. R.L. Wiener and PF. Pound, Report on State Medical Board Interviews, Project on Legal Constraints on Access to Effective Pain Relief, Dept. of Psychology, St. I ouis University (1996).

25. Project on Legal Constraints on Access to Effective Pain Relicf, American Society of Law, Medicine \& Ethics, The Pain Relief Act (1996) (as cited in Journal of Law, Medicine Lo Lithics, 24 (1996): 317-18; see also at http://wwwaslme.org).

26. Scc, for example, Federation of State Medical Boards, Report of the Ad Hoc Conmittee on Physician Impairment (Apr. 1995).

27. See, for example, United Siates $v$. Jones, 570 F.2d 76.5 (8th Cir. 1978); and United States v. Mahar, 801 F.2d 1477 (6th Cir. 1986).

28. General Accounting Office, supra note 16; and Soumerai et al., supra note 16 .

29. B.B. Wilford et al., "An Overview of Prescription Drug Misuse and Abuse: Defining the Problem and Sceking Solutions," Journal of Law, Medicine \& Etbics, 22 (1994): 197-203; and R.S. Shapiro, "Legal Bases for the Control of Analgesic Drugs," Journal of Pain and Symptom Management, 9 (1994): 153-59. The scope of this problem is largely undocumented. See J.R. Cooper et al., "Prescription Drug Diversion Control and Medical Practice," JAMA, 268 (1992): 1.306-10.

30. See D. F. Joranson, "Intractable Pain Treatment Laws and Regulations," American Pain Society Bulletin, Mar/Apr. (1995): 1-3, 15-17; and D.E. Joranson, "State Medical Board Guidelines for 'Ircatment of Intractable Pain," American Pain Society Bulletin, May/June (1995): 1-.5. Thet most well known and comprehensive regulation is California's. See State of California, Sinmit on Effective Pain Management: Renoving Impediments to Appropriate Prescribing (Mar. 18, 1994); and Medical Board of California, "Statement by the Medical Board," Action Report, 50 (Iuly 1994): 4-5. One of the more recent is the proposed regulation developed by the New Jersey State Board of Medical Examiners. Proposed N.J. Adnuin. Code tit. 13:35-7-6 (1996).

31. Sec Wiener and Pourt, supra note 24.

32. See Group Health Plan, Inc., 787 S.W.2d 745 (discussing the appropriatencss of a declaratory judgment action agaiust the board for threats of disciplinary action where no disciplinary action was actually being pursued).

33. Sec, for example, Fattá v. State Medical Board of Obio, 1994 WL 73903 (Ohio App. 1994); Brown v. Louisiana State Board of Medical Examiners, 637 So. 2d 1113 (La. App. 1994); DiLen, 661 So. $2 \mathrm{~d} \mathrm{162;}$ and People v. Schade, 32 Cal. Rptr. $2 \mathrm{~d}$ 59 (Cal. App. 1994). 3-25a.

34. B.R. Furrow et al., Health Law (St. Paul: West, 1995): $\$$

35. Many such organizations are developing guidelines. The Agency for Health Care Policy and Research, a federal agency, has developed several. See, for example, American Pain Society Quality of Care Committee, "Quality Improvement Guidelines for the Treatment of Acute Pair and Cancer Pain," JAMA, 274 (1995): 1874-80; P. Crowley, "No Pain, No Gain?" The Agency for Health Carc Policy and Rescarch's Artempt to Change Intef- ficient Health Care Practice of Withholding Medication from Patients in Pain," Journal of Contemporary Health Law and Policy, 10 (1993): 383-403; and Agency for Health Care Policy and Research, supra note 5 .

36. Medical Board of California, "Clinical Practice Guidelines: Cancer Pain Management," Action Report, 49 (Apr. 1994): 6.

37. General Accounting Office, Practice Guidelines: The Experience of Medical Specialty Societies (Washington, D.C.: Gencral Accounting Office, 1991).

38. D.E. Joranson and A.M. Gilson, "Policy Issues and Imperatives in the Use of Opioids to Treat Pain in Substance Abusers," Journal of Law, Medicine \& Eithics, 22 (1994): 21523. Diagnosis of addiction may depend on the specialty and background of the diagnostician, with pain specialists and addiction specialists reaching different conclusions. See, for example, S.R. Savage, "Pain Medicine and Addiction Medicine-Controversies and Collaboration," Joumal of Pain and Symptom Management, 8 (1993): 254-56. Courts have also had difficulty in interpreting the terms addiction and dependency. Sec, for example, Schade, 32 Cal. Rptr. 2d 59. But sec, Reynolds v. Louisiana State Board of Medical Examiners, 646 So. $2 d 1244$ (Ia. App. 1994) (holding that the board's discipline of physician for prescription of controlled substances for persons who were "abusing" was supported by sufficient evidence).

39. Cal. Bus. \& Prof. Code $\$ 2241.5$ (West 1994); Fla. Stat. Ann. $\$ 458.326$ (West 1995); Mo. Ann. Stat. $\$ \$ 334.105$ et seq. (Vernon 1995); Nev. Rev. Stat. $\$ 630.3066$ (1995); N.D. Cent. Code $\$ \$ 19-03.3-01$ et seq. (1995); Or. Rev. Stat. $\$ \$ 677.470$ ct seq. (1995); Tex. Rev. Civ. Stat. Ann. art. 4495c (West 1996); and Va. Code Ann. \$54.1-3408.1 (Michie 1995).

40. See, for example, 1996 Ariz. H.B. 2362; and 1996 N.J. A.B. 1482 .

41. Cal. Bus. \& Prof. Code $\$ 2241.5$ (West 1994).

42. Nev. Rev. Stat. $\$ 630.3066(1995)$; Or. Rev. Stat. $\$ 677.475$

(1995); and Tex. Rev. Civ. Stat. Ann. art. 4495c (West 1996).

43. Va. Code Ann. $\$ 54.1-3408.1$ (Michie 1995).

44. Fla. Stat. Ann. $\$ 458.326$ (West 199.5).

45. Nev. Rev. Stat. $\$ 630.3066$ (1995).

46. Cal. Bus. \& Prof. Code $\$ 2251.5($ b) (West 1994). Sce also Or. Rev. Stat. $\$ 677.470(2)(1995)$.

47. N.D. Cent. Code $\$ 19-03.3-05$ (1995); Tex. Rev. Civ. Stat. Ann. art. 4495c (West 1996); and Cal. Bus. \& Prof. Code $\$$ 2241.5 (West 1994).

48. Sce, for exarnple, Mo. Stat. $\$ 334.106(3)$ (Vernon 1995) (but see $\$ 334.101(\mathrm{~d})(4)$, providing that "drug dependency" is not a sufficient reason for withholding pain medication); Tex. Rev. Civ. Stat. Ann. art. 4495c(6)(b) (West 1996); N.D. Cent. Code $\$ 19-03.3-05$ (1995); and Cal. Bus. \& Prof. Code $\$$ 2241.5(e) (West 1994).

49. Or. Rev. Stat. $\$ 677.485$ (1995).

50. See, for example, L.F. Post et al., "Pain: Ethics, Culture, and Informed Consent to Relief," Journal of Law, Medicine Ethics, 24 (1996): at 348 n.1.

51. Sce, for example, Del. Code Ann. tit. 16, $\$ \$ 2.505,2510$ (Michie Supp. 1995); Ohio Rev. Code Ann. $\$ 2133.12(\mathrm{I})(1)$ (Baldwin 1994); Va. Code Ann. $\$ 54.1-2984$ (Michie 1995). But see Md. Health-Gen. Code Ann., $\$ 5-603$ (Michie Supp. 1996) (providing an option on the advance directive form to allow the patient to direct that pain medication not be given if it would shorten the patient's life). 